\title{
Social Media and the Murder of Klodian Rasha
}

\author{
Isida Hoxha (Haxhi) \\ PhD, University of Shkodër, "Luigj Gurakuqi”, Albania
}

\begin{abstract}
Social media brought an important change in the way of doing journalism, different from traditional media for their characteristics and features on their own. As every new thing, social media attracts the attention of researchers to understand the way how they function with their advantages and disadvantages, with positive and negative aspects. The murder of an innocent young man by a policeman in Tirana in the December of 2020 had a lot of attention in Albania media. The sensitivity of Albanian society in this case, despite the event itself was strengthen from the media space that was given to the murder, given versions of official and unofficial sources and protests organized in the name of the victim Klodian Rasha. This case study was analyzed to understand the role of social media focusing in the process of producing the media product, spreading, network, interaction in other words the new media space and ethical problems that accompany this process so the research question is: Which is the role of social media in covering and treatment of this event? The study relies on the social platform Facebook because it is one of the most followed platforms in Albania.
\end{abstract}

Keywords: social media, Facebook, democratic space, ethical issues

\section{Introduction}

The murder of Klodian Rasha, the young man who lost his life because of a policeman, expanded the anger of people and was accompanied with protests for several days culminating in the resignation of the interior minister Sandër Lleshaj. From all the events which occur daily, only a few are deemed to be newsworthy enough to be reported as news. This event became news in traditional media and social media because it completed the criteria that news requires which is "the final result of a complex process that started with a regulation and selection of the event and themes according to a specific social category." (Hall, 1978:53). This selection of the event is focused on some attributes of the event, some of them according to Galtung \& Ruge (1965) are: the unexpected, the main negative consequences, their effect on the social elite, violent attacks, attractive pictures and their impact on many people. This event became news, being included in the social media agenda not only as a result of the above attributes but also the features of social media; therefore, the study will refer to the news on social media and more specifically on the Facebook platform.

\section{The role of the media, democratic space}

The definitions of the social media are numerous by influencing in the difficulties of creating a theoretical framework as they are constantly evolving. Different from traditional media where we are dealing with one-way communication defined by a group of professionals, on 
social media users participate in the content of the media product. According to Kaplan \& Haenlein (2010: 61), social media is a group of applications based on the Internet, which are built on the ideological and technological foundation of Web 2.0 that allow the creation and exchange of user's content on the network.

Social media can play an important role for users, as it provides a platform that allows users to express their thoughts and attitudes. Researchers Coleman and Ross (2010:94-95) highlight some key issues related to the changes brought by digital media and the internet, which enable the creation of a more democratic media space such as destroying the dominance of the elite in the production and spread of information; expanding the range of media resources as anyone can become a producer of media content; the formation of communication networks and the interconnection between them facilitating the formation of the public beyond physical distances; interactive communication space where message senders can be returned to the recipient of the message according to the very-direct-very communication model. The new media space has opened the possibility to share, reflect, compare on the views and experiences of the public, creating space for public discussion, in which positions are reviewable. Through social networks, various citizens and civil society activists organized to hold a peaceful rally, in protest, a day after the execution of 25 -year-old Klodian Rasha by police. The message that circulated on social networks:

"The murder of 25-year-old Klodian Rasha in the middle of the night on the doorstep of the house, in every possible circumstance, is an alarm bell for order and security in the country. Without giving a logical and legal reasoning, a person in a State Police uniform executes a young man "because he suspected he was a threat to law and order". Tomorrow, 09.12.2020, at 16:30 in front of the Ministry of Interior, WE PROTEST! The rally will be peaceful and in accordance with the protocols of the pandemic, we do not determine the participation, but how much is the civic sensitivity for the importance of life. Life is more important than the doubt of an effective. Take this copy paste message and publish it on your profile. All with each other for each other. SPREAD!!!!!!”.1

After this call, where the recipients of the message simultaneously became the sender of the message, thousands of citizens gathered in the square in Tirana to protest, not only on December 9, but also in the following days. The protests escalated at the national level, dividing into two positions not only the political and cultural elite but also well-known Albanian figures in terms of protests and their consequences. The event was used politically by the two main camps: From the government led by Rama trying to keep the situation under control and in the other camp the accusations made responsible Rama government for the event and manipulation ${ }^{2}$ of the murder of Klodian Rasha. These political actors certainly serve as resources for the importance they have, thus maintaining their hegemonic role, "the superiors fabricate and maintain the support for their dominance over the inferior and propagandists in favor of the propagandists." (McNair, 2009: 71). But if the traditional media serve as institutions to maintain the superiority of this class, in social media there is a greater freedom in relation to resources as everyone can become a producer of media content, thus reducing the dominance of elite production and dissemination of information. The victim's

\footnotetext{
${ }^{1}$ https://www.faxweb.al/organizimi-per-klodian-rrashen-e-merkure-9dhjetor/?fbclid=IwAR0wAduty6gYflPEtPwO0xtfNjPiPuovs4KIDSPskbsiDz8Wsk_k_nc7tTo 2 https://opinion.al/basha-takim-me-reporteret-e-pe-po-manipulojne-vrasjen-e-klodianrashes/?fbclid=IwAR2vXiLWLpYhs61230H1u9ubbQG48Zw9Q3BSa6osLADI4hgfUzA_TSoiBME
} 
father is an important source, and all the time in his statements he demands justice for his son, not mercy ${ }^{1}$. A public letter circulated on the network when the victim's father called for no incidents during the protests: "What Albanians are already doing is a revolt of Albanians for freedom, justice, love ... And honorable do not forget that justice did not come from the police, the court or the interior minister who clearly did not want to take responsibilities, it only came from those people who protested...".2 Despite the physical distances of the public and facebook users, the formation of communication networks and the interconnection between them, influence the creation of social capital. To explain this, we will refer to the Putnam researcher according to whom: "we describe social networks and associated norms of reciprocity as social capital, because social networks create value, both individually and collectively, and because we can "invest" in networking" (2002:7). According to Putnam (2002:6), the basic idea of social capital is that a person's family, friends, and associates constitute an important asset, one that can be called on in a crisis, enjoyed for its own sake, and leveraged for material gain. What is true for individuals, moreover, also holds for groups. Those communities endowed with a diverse stock of social networks and civic associations are in a stronger position to confront poverty and vulnerability, resolve disputes, and take advantage of new opportunities. In this case, individuals and groups through these links on social media gained stronger positions through participation in public life to protest for the right of Klodian Rasha and for justice.

\section{Ethical issues}

One of the biggest problems faced by the media not only in Albania, but also outside Albania, has to do with ethical issues. Although ethical issues are often classified more theoretically, according to David Randall, ethics should not be seen as a codification of behavior, but "as a definition not just of the principles but of the good practices of journalists" (2003:120). Social media as a result of technological development is playing an increasingly important role as we discussed above, but despite the advantages in relation to the democratic media space, the risk lies precisely in this positive feature. The possibility for anyone to be a journalist, throwing in information that may not be accurate, verifiable, etc., is contrary to the basic principles of journalism. "Being fluid and interactive as well as being global, digital media is becoming a shelter for important ethical issues, as our communication can easily and quickly spread to a large number of people around the globe, then this makes us more cosmopolitan in unseen new ways" (Ess, 2014:13). Despite the difficulties in establishing a theoretical framework for the ethics of digital media as a result of cultural differences in different societies, in Albania concrete initiatives have been undertaken and serve as guides for the ethics of media outlets such as "Ethical code of journalists" or "Ethical instructions for online journalism". Online journalism must respect the basic values of journalism, therefore the information published in the media must be "accurate and fact-based, verified and not sensational, published without the intention of harming third parties, to impartially involve all relevant efforts, to be transparent about the origin of the content and the journalistic methods used"3. Despite the information, the duty and responsibility of the editorial office is

\footnotetext{
${ }^{1}$ https://www.faxweb.al/rexhep-rasha-deshmia-e-dyte-per-ngjarjen/?fbclid=IwAR3KzGmta09XHIhfrh38MOXkqVqozRLLGCGRkkQyzkhrEVlEecHtBZl-Qw 2 https://www.tpz.al/2020/12/13/protestat-per-klodian-rashen-ultrasit-e-tirones-leter-publike-teatit-vrasja-sju-perket-vetem-ju-si-familje-ke-ulur-koken-nga-presioni/
} 
to "monitor the online site (and relevant social media sites) and take measures to prevent or stop the publication of illegal materials that violate privacy and human dignity, or include hate speech. Whenever possible, monitoring should be done prior to publication"1. The protests that followed the December 8 event brought different attitudes of ordinary citizens or people enjoying a public status, which also produced public debates. One of the controversies that was accompanied by ethical problems, started with a post by Einxhell Shkira, who posted a status where she states the reasons why she did not go out in protest, because for her, there is no sense of a protest associated with the burning of the city of Tirana. A reply in an unethical language is posted by the singer Stresi, in the direction of Shkira, a reply which is published by all the media from those with less weight to the main media in the albanian media market as "Top Channel". In this article, it is not considered reasonable to cite the status of the singer because of the language used that exceeds ethical goals, but is cited a part of the answer from Shkira: "You are the one who solves things with weapons and violence. You are the one who incites violence in those who follow him and feeds them with successive crimes"2. After the public lynching of the moderator, on social networks, her interview on the show "Invitation to the Five", talks about the difficulties to manage this issue: "I could have been a depressed person and from all what happened I could have drunk two pills, killed myself and come on then how are we going to solve it? For whom would we then go out in protest? For a person whose life was virtually ruined? We or those who did this are criminals every day. They are no better than the policeman who killed Klodian"3, - said Shkira. One of the phenomena observed on social media is the publication of news, distancing itself from the ethical issues that accompany the news, transferring all responsibilities to the source of the news. In fact, the editorial office should be careful what it publishes on its website because it takes ethical and potentially legal responsibility for the content generated by third parties.

One of the basic principles of ethics is to take care of the language used, and more specifically hate speech which "is understood as expressions intended to incite deep hatred, real violence or discrimination against certain individuals or groups"4.

In the protests that involved thousands of citizens, there is no lack of expressed attitudes through acts that are classified as illegal. One of the names involved in the protests and declared wanted by the police with a series of charges such as "Organizing and participating in illegal rallies", "Obstruction of the circulation of means of transport", "Objection to a public order police officer", "Disturbance of public order", "Destruction of property by fire" and "Disobedience to the order of a public order police officer", was also the singer Stresi. In one of the posts, taken from the video published in his profile on Instagram, Stresi addresses Prime Minister Rama:

"Rama, hand over Ardi Veliu, if you do not hand over your doll, your house in Surrel will burn down. The biggest criminal"5. Similar posts are often published on social media. In line with the "Ethical Guidelines for Online Journalism", there is also the "Code of Ethics for Journalists",

\footnotetext{
1 UDHËZIME-ETIKE-PËR-GAZETARINË-ONLINE-3.pdf (kshm.al)

2 https://top-channel.tv/2020/12/11/protesta-per-klodian-rashen-kur-flet-edhe-ti-qe-plas-sherrimes-stresit-dhe-einxhel-shkires-foto/

3 https://news-31.com/einxhel-shkira-perlotet-teksa-flet-per-konfliktin-me-stresin-nuk-jane-me-temire-se-polici-qe-vrau-klodianin/

4 UDHËZIME-ETIKE-PËR-GAZETARINË-ONLINE-3.pdf (kshm.al)

5 https://opinion.al/gjalle-a-vdek-sot-do-jem-ne-proteste-stresi-rames-do-vijme-ne-surrel/
} 
the principles of which are in line with the ethical values that are classified as necessary by professionals in the field, for all types of media including social media. One of the principles contained in this code of ethics is "Violence and brutality should not be sensationalized"1. As a result of the democratization of media space, resources have more freedom, democracy, but when Bertrand explains Habermas radical democracy, he says that it "requires honest filters, trusted journalists, who are competent and reasonable" (2007:8). If we read the response of Sali Lushaj (father of the singer Stresi and former bodyguard of Sali Berisha), to an article by analyst Frrok Çupi, we come across the following lines:

"To use a gun you should be a man! You are a mule, neither man nor woman. And if the bullets were from sh .. believe me I would not have spared you! But there was also a small spy with a file, a toilet Frok Çufrra! I just read an article in the newspapers, I apologize for the expression "Tema as well as the Shqiptarja.com" of the published journalist Karlo without n...! For that god I had remembered that he does not live with stupidity! I went online and saw his photos!... Your friends told me that you have been farting for a long time and shouting in the streets and newsrooms. I have been and remain the opponent of Enver, ZP, of all those you served and the filth like you and them! You were born and lived like a bastard...Tonight I gave you a lot of attention fucking idiot!"2.

The above article holds the editorial office ethically responsible, even though the content is generated by a third party, because journalists are required to respect the ethics of public expression during reporting or controversy. It is also obvious that the language used is classified as hate speech, contrary to the codes of ethics for online journalism.

\section{Sensational titles and impartiality}

The titles of the articles are important because they attract the attention of readers and users in a constant media competition. According to Rugova, "the thematic function of the title is to present the topic and the summary of the main element of the writing, or rather, of what the sender considers a priority during the announcement" (2009: 136), as media professionals know that readers read the headlines more often than the articles. "In the economic battle for readers or users, even those media outlets that were considered the most credible and prestigious could not escape the tendency to use sensational headlines to artificially increase the number of clicks" (Londo, 2020:19). Such a phenomenon is commonly encountered in media which are less credible, but not only, as titles that do not correspond to the content, or sensational titles are often placed in the main Albanian media. In the article published entitled "Exclusive / Nothing was a coincidence! Klodian Rasha and Nevaldo Hajdaraj knew each other, had worked together... (the policeman used drugs)", there are essential differences in relation to the content, as in the narrative of the article the facts differ compared to the established title. The content says that "As for the first track, despite not being officially declared, it turns out that Rasha and Hajdaraj at least physically knew each other... From information still

\footnotetext{
${ }^{1}$ Kodi i Etikës së Gazetarit - Këshilli Shqiptar i Medias (kshm.al)

2 https://tirananews.al/sali-lushaj-i-pergjigjet-frrok-cupit-plumbat-nuk-ti-kisha-kursyer-skam-dashurderi-me-sot-ta-ndyj-tyten-e-kallashit-me-ty-djali-im-ju-tmerroi-te-gjitheve/?fbclid=IwAR32NsqYmx_96Ps1yXYJi8KuWosNpdNizLQjGTi3qgCZDbZpiQxZrk7L_4
} 
unconfirmed, there are suspicions that Rasha and Hajdaraj even worked together some time ago in a business on "Bardhyl" street in the capital"1.

Another problem identified in the Albanian media is the bias of the media. This problem is evidenced by the media itself, as highlighted below:

"Today, the media close to Prime Minister Rama, have brought back to attention the event of January 21, 2011, where four citizens were killed on "Dëshmorët e Kombit" boulevard, near the Prime Minister, after a protest organized by the PS, which was then in opposition while the current leader of PD, Basha, was interior minister. The media close to Rama write that even Basha did not resign at that time, even though four innocent people were killed in the square. They also compare December 8 to January 21 to relativize the murder of 25-year-old Klodian Rasha two days ago. "According to them, neither Basha nor Prime Minister Berisha resigned despite the killing of four citizens" 2 .

Although one of the principles included in the Code of Ethics of the journalist is that journalists should provide impartial and balanced reporting, often it doesn't work.

\section{Conclusion}

In the case of Klodian Rasha, social media enabled the creation of a more democratic media space, the expansion of the range of resources used, the formation of communication networks and interactivity. Unlike traditional media, which maintained the dominance of the elite in the production and dissemination of information, in this case social media have contributed to the creation of media spaces that not only allow information to the public through two-way communication but also strengthen ties between citizens. Ethical issues in the media, although they may seem like an outdated topic, return strongly because social media, among other things, brought to the attention of scholars ethical problems. One of the key ethical principles is that information must be accurate, balanced and verified. Accuracy and verification are important elements in the search for the truth in journalism, but often on social media this remains a difficult process to accomplish.

\section{Bibliography}

[1] Bertrand, J. C. (2007). Deontologjia e mediave. Instituti Shqiptar i Medias.

[2] Coleman, S., \& Ross, K. (2010). The Media and the Public. "Them" and "Us" in media Discourse. Wiley Blackwell Publishing.

[3] Ess, C. (2014). Etika e mediave dixhitale. Instituti Shqiptar i Medias.

[4] Galtung, J., \& Ruge, M. H. (1965). The Structure of Foreign News. Journal of Peace Research, 2 (1), 64-91. https://www.jstor.org/stable/423011

[5] Hall, S., Critcher, C., Jeffeson, T., Clarke, J., \& Roberts, B. (1978). Policing the crisis: mugging, the state, and law and order. Macmillan.

\footnotetext{
${ }^{1}$ https://www.faxweb.al/klodian-rasha-dhe-nevaldo-hajdaraj-faxweb/

2https://hashtag.al/index.php/2020/12/10/si-po-e-mbrojne-qeverisjen-e-rames-mediet-afertij/?fbclid=IwAR0g5V_2Y9RNRpeZPI8003hyfmpaz3yWG5_Hlx3fBKgmsxDzy5iXbVCSGnI
} 
[6] Londo, I. (2020). Gjuha e urrejtjes, propaganda dhe dezinformimi në median shqiptare. Instituti Shqiptar i Medias.

[7] McNair, B. (2009). Hyrje në Komunikimin Politik. Maluka.

[8] Putnam, R. D. (2002). Democracies in Flux: The evolution of social capital in contemporary society. Oxford University Press.

[9] Randall, D. (2003). Gazetari Universal. Instituti Shqiptar i Medias.

[10] Rugova, B. (2009). Gjuha e Gazetave. Koha.

[11] Kaplan, A. M., \& Haenlein, M. (2010). Users of the world, unite! The challenges and opportunities of social media. Business Horizons, 59-68.

[12] Dervishi, L., Marku, M., \& Lani. R. (2018). Kodi i etikës së gazetarit. Kodi i Etikës së Gazetarit - Këshilli Shqiptar i Medias (kshm.al)

[13] Pavli, D., \& Salaj, B. (2018). Udhëzime etike për gazetarinë online. Instituti Shqiptar i Medias. UDHËZIME-ETIKE-PËR-GAZETARINË-ONLINE-3.pdf (kshm.al)

[14] Si po e mbrojnë qeverisjen e Ramës mediet afër tij. (2020, December 10). Hashtag.al https://hashtag.al/index.php/2020/12/10/si-po-e-mbrojne-qeverisjen-e-ramesmediet-afer-

tij/?fbclid=IwAR0g5V_2Y9RNRpeZPI8003hyfmpaz3yWG5_Hlx3fBKgmsxDzy5iXbVC SGnI

[15] Basha takim me reporterët e PE: Po manipulojnë vrasjen e Klodian Rashës. (2020, December 14). Opinion https://opinion.al/basha-takim-me-reporteret-e-pe-pomanipulojne-vrasjen-e-klodian-

rashes/?fbclid=IwAR2vXiLWLpYhs61230H1u9ubbQG48Zw9Q3BSa6osLADI4hgfUzA -TSoiBME

[16] “Gjallë a vdek sot do jem në protestë”, Stresi-Ramës: Do vijmë në Surrel. (2020, December 12). Opinion https://opinion.al/gjalle-a-vdek-sot-do-jem-ne-protestestresi-rames-do-vijme-ne-surrel/

[17] Einxhel Shkira përlotet teksa flet për konfliktin me Stresin. Nuk janë më të mirë se polici që vrau Klodianin. (2020, December). Neës-31 https://news-31.com/einxhelshkira-perlotet-teksa-flet-per-konfliktin-me-stresin-nuk-jane-me-te-mire-se-policiqe-vrau-klodianin/

[18] Sali Lushaj i përgjigjet Frrok Çupit: Plumbat nuk t'i kisha kursyer. (2020, December 15). Tirananews https://tirananews.al/sali-lushaj-i-pergjigjet-frrok-cupit-plumbatnuk-ti-kisha-kursyer-skam-dashur-deri-me-sot-ta-ndyj-tyten-e-kallashit-me-tydjali-im-ju-tmerroi-te-gjitheve/?fbclid=IwAR32 NsqYmx_96Ps1yXYJi8KuWosNpdNizLQjGTi3qgCZDbZpiQxZrk7L_4

[19] Protesta për Klodian Rashën/ "Kur flet edhe ti që..." Plas sherri mes Stresit dhe Einxhel Shkirës. (2020, December 11) Top-Channel https://topchannel.tv/2020/12/11/protesta-per-klodian-rashen-kur-flet-edhe-ti-qe-plassherri-mes-stresit-dhe-einxhel-shkires-foto/ 
[20] Ekskluzive/ Asgjë nuk ishte rastësi! Klodian Rasha dhe Nevaldo Hajdaraj njiheshin mes tyre, kishin punuar së bashku. (2020, January 3). Fax Web https://www.faxweb.al/klodian-rasha-dhe-nevaldo-hajdaraj-faxweb/

[21] Vrasja e Klodian Rashës nga policia, qytetarët organizohen për tubim masiv përballë Ministrisë së Brendshme. (2020, December 8). Fax Web https://www.faxweb.al/organizimi-per-klodian-rrashen-e-merkure-9dhjetor/?fbclid=IwAR0wAduty6gYflPEtPw00xtfNjPiPuovs4KIDSPskbsiDz8Wsk_k_n c7tTo

[22] “I kam edhe unë ca gjëra në xhep", nuk ndalet Qazim Rasha: Nuk e dua pensionin e qeverisë, nuk ia kam shtrirë dorën askujt. (2020, December 15). Fax Web https://www.faxweb.al/rexhep-rasha-deshmia-e-dyte-perngjarjen/?fbclid=IwAR3KzGmta09XHIhfrh38M0XkqVqozRLLGCGRkkQyzkhrEVlEecHtBZl-Qw

[23] Protestat për Klodian Rashën/ Ultrasit e 'Tironës' letër publike të atit: Vrasja s'ju përket vetëm ju si familje. (2020, December 13). TPZ.al https://www.tpz.al/2020/12/13/protestat-per-klodian-rashen-ultrasit-e-tironesleter-publike-te-atit-vrasja-sju-perket-vetem-ju-si-familje-ke-ulur-koken-ngapresioni/ 